\title{
Desain Modifikasi Struktur Apartemen Puncak Dharma Husada Surabaya Dengan Kombinasi Shearwall Dan Outrigger System
}

\author{
Angga Bayu Christianto, Tavio, dan I Gusti Putu Raka \\ Departemen Teknik Sipil, Fakultas Teknik Sipil dan Perencanaan, Institut Teknologi Sepuluh Nopember (ITS) \\ e-mail:raka@ce.its.ac.id
}

\begin{abstract}
Abstrak-Perkembangan pesat dan industrialisasi besar di kota metropolitan menyebabkan naiknya angka urbanisasi ke kota tersebut. Dengan minimnya lahan diperkotaan, perlu dikembangkan bangunan vertikal. Pengembangan ini rentan terhadap beban lateral seperti angin dan gempa. Dengan demikian, para insinyur harus solutif dalam memilih sistem mana yang digunakan untuk merancang bangunan. Pemilihan sistem harus mempertimbangkan aspek kekuatan dan efisiensi sistem struktur karena bangunan yang kuat menahan gaya gempa memerlukan biaya konstruksi yang sangat mahal. Apartemen Puncak Dharma Husada berkapasitas 40 lantai menggunakan kombinasi shearwall dan outrigger system. Outrigger merupakan elemen struktur terdiri dari balok setinggi satu lantai yang berfungsi untuk meningkatkan kekakuan keseluruhan bangunan sehingga dapat mereduksi dimensi balok dan kolom. Meningkatnya kekakuan juga dapat mengurangi periode dan simpangan bangunan. Pada tugas akhir ini, elemen outrigger dan belt truss, dimana outrigger dirancang sebagai balok tinggi beton bertulang dan belt truss yang dirancang sebagai struktur rangka yang terbuat dari baja.
\end{abstract}

Kata Kunci-Belt Truss, Outrigger, Beton Bertulang, Shear Wall, Struktur Baja.

\section{PENDAHULUAN}

$\mathrm{S}$ URABAYA merupakan salah satu kota besar di Indonesia, dimana keterbatasannya lahan kosong sehinggah mengharuskan pola pembangunan gedung secara vertical. Pembangunan gedung secara vertical sangat rentan terhadap bahaya beban lateral seperti beban angin dan gempa. Untuk mengatasi masalah tersebut beberapa elemen dari gedung harus dirancang sedemikian rupa sehingga mampu menahan beban lateral yang terjadi. Elemen utama gedung yang harus direncanakan terhadap pengaruh beban gempa antara lain balok, kolom, dan dinding geser.

Gedung Puncak Darma Husada (PDH), Apartement 40 lantai, merupakan gedung dengan konstruksi sistem ganda, dimana sistemnya terdiri dari rangka pemikul momen (balok dan kolom) dan dinding geser yang bekerja bersama-sama untuk menahan beban gravitasi hingga lateral (beban angin dan gempa). Sebagian besar atau $75 \%$ beban latertal (angin dan gempa) dipikul oleh dinding geser sehinngga membuat dimensi dinding geser yang dibutuhkan menjadi besar karena momen lentur dan gaya geser yang harus ditahannya [1]. Sehingga dinding geser yang digunakan perlu dianalisis keefektifitasannya karena semakin besar dimensi dinding geser semakin besar pula biaya konstruksinya.

Akan tetapi karena kebutuhan untuk estetika ruang yang lapang maka dimensi elemen bangunan dibuat seminim mungkin. Oleh karena itu akan dipasang system outrigger pada gedung PDH ini dengan mengkombinasikannya pada dinding geser. Outrigger sendiri merupakan komponen dari dinding yang berfungsi sebagai balok setinggi satu lantai. Penggunaan outrigger dapat mengurangi momen yang terjadi pada dinding geser beserta kolom dinding geser sehingga bertujuan untuk memberikan kekakuan dalam mengurangi beban lateral. Hal ini dapat mengakibatkan dimensi dinding geser dapat direduksi. Penggunaan outrigger juga dapat menambah kekakuan struktur gedung. Penambahan kekakuan tersebut juga dapat mengurangi periode bangunan dan drift maksimum struktur yang berdampak pada kenyamanan pengguni yang merupakan aspek paling penting [2].

Dalam tugas akhir ini penulis merancang ulang desain Apartemen yang awalnya 39 (tiga puluh Sembilan) lantai dengan 1 (satu) lantai basement, 1 (satu) lantai atap, dan 37 (tiga puluh tujuh) lantai gedung dirubah menjadi 40 (empat puluh) lantai dengan menaikkan 1 (satu) lantai basement dan menambah satu lantai untuk lantai atap.

\section{METODE STUDI}

A. Outrigger System

Outrigger system merupakan sistem yang paling baru bagi Negara kita karena aplikasinya masih relatif sedikit dibandingkan sistem konvensional. Outrigger system memiliki ke efisiensian yang bisa sampai 150 lantai. Hong Kong Cheung Kong Center (290 m), Hong Kong IFC2 (380 m), Hong Kong ICC (450 m), Taipei 101 (509 m), Guangzhou CTF Tower $(520 \mathrm{~m})$ adalah contoh tipe gedung tinggi yang menggunakan sistem outrigger. Dengan tinggi bangunan yang terus meningkat desain bangunan akan dikendalikan oleh kekakuan dan perpindahan. Dengan prisnsip engineering yang simple seperti pada (Gambar 2.1), daya tahan lateral meningkat apabila struktur di pinggir dapat bergandengan dengan struktur inti (Gambar 2.1 (1b)). Selain itu semakin tinggi balok yang membentang dari inti bangunan ke pinggir bangunan, maka semakin kaku pula bangunan tersebut [3].

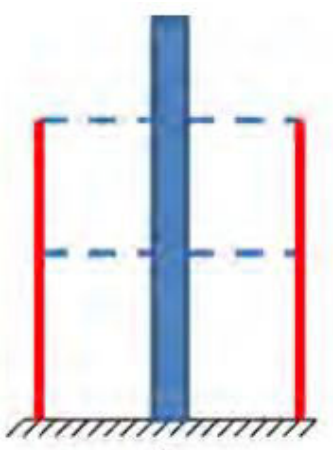

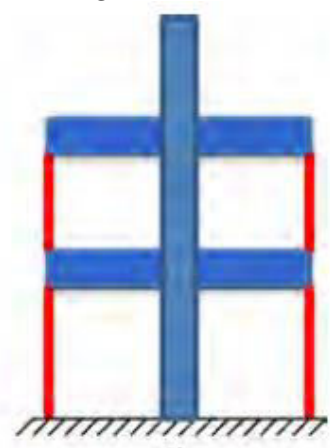

Gambar 1. Model 2D yang menunjukkan bangunan dengan atau tanpa balok tinggi.

Oleh karena itu, engineer mulai mempertimbangkan untuk menggunakan balok pengaku untuk menghubungkan inti bangunan dan pinggir bangunan. Hal tersebut menjelaskan bahwa semakin kaku balok yang digunakan maka juga akan meningkatkan kekakuan lateral dari bangunan. Ketika ketinggian suatu bangunan bertambah, akan sangat sulit menerapkan konsep balok kaku, oleh karena itu dikembangkan sistem outrigger. Outrigger sendiri merupakan sebuah komponen struktur (balok tinggi) yang berfungsi menghubungkan kolom eksterior melalui belt truss dengan shear wall dan berguna untuk menambah kekakuan pada bangunan dengan mengubah gaya lateral menjadi gaya tarik dan gaya tekan pada pinggir struktur [3]. Oleh sebab itu, outrigger dibutuhkan untuk menolak, membalik, dan memutar beban. Dari prinsip engineer, topologi dari sistem outrigger harus simetris untuk beban keatas dan beban kebawah yang menyediakan kemampuan yang sama dalam semua bentuk beban. Jika topologi yang simetris tidak dapat dipakai, maka 
engineer harus berhati-hati dengan kalakuan outrigger terhadap beban putar [3].

\section{B. Keuntungan Menggunakan Outrigger system}

Berikut merupakan beberapa keuntungan menggunakan outrigger system:

1. Momen yang berputar pada inti dan peningkatan deformasi yang terjadi dapat dikurangi melalui momen yang berputar berlawanan arah yang bekerja pada shear wall pada masing-masing persimpangan outrigger. Momen ini ditimbulkan dari pasangan gaya pada kolom terluar yang terhubung dengan outrigger.

2. Pengurangan yang signifikan dan kemungkinan hilangnya gaya ke atas dan gaya regang melalui kolom dan pondasi.

3. Penempatan jarak kolom terluar tidak didasarkan pada pertimbangan structural saja dan dapat dengan mudah dikaitkan dengan pertimbangan estetika dan fungsional.

4. Framing terluar dapat berupa balok biasa yang sederhana dan framing kolom tanpa harus membutuhkan sambungan frame yang kaku, mengakibatkan perancangan bangunan lebih ekonomis.

\section{Kelemahan Menggunakan Outrigger System}

Setiap sistem perencanaan dan material struktur tentunya memiliki keunggulan dan kelemahannya masing-masing. Seperti halnya outrigger memiliki beberapa kelemahan sebagai berikut:

1. Ruang yang terpakai akibat pemasangan outrigger memakan banyak tempat di lantai dimana outrigger dipasang, sehingga berkemungkinan satu lantai yang menggunakan outrigger tidak dapat difungsikan sebagai mana mestinya, kecuali untuk gudang atau ruang service.

2. Pada umumnya kekakuan pada outrigger sangat tinggi, lendutan vertikal kecil yang disebabkan penyusutan dari kerangka inti dan tepi terutama karena lendutan elastis, susut dan rangkak, akan menyebabkan gaya yang sangat besar pada elemen outrigger. Meskipun engineer dapat dengan mudah memprediksi berapa besar penyusutan elastis, susut dan rangkak keduanya bergantung pada variabel waktu. Itu juga menjelaskan bahwa susut dan rangkak tidak akan terjadi saat bangunan suda jadi atau dalam pengerjaan.

3. Cara menghubungkan outrigger dengan shearwall dapat menjadi suatu hal yang sangat rumit. Tingkat kesulitan akan semakin tinggi apabila sistem outrigger dan shear wall memiliki perbedaan bahan (beton dan baja).

\section{ANALISIS DAN PEMBAHASAN}

\section{A. Struktur Sekunder}

1. Plat Lantai Apartement Puncak Dharmahusada

- Pelat lantai $\mathrm{t} \quad=120 \mathrm{~mm}$

- Pelat atap $\mathrm{t} \quad=120 \mathrm{~mm}$

2. Perhitungan Balok Anak

- Lantai atap 20/30

- Lantai apartemen 20/30

3. Perhitungan Balok Penumpu Lift
Tipe lift
Merek
Kapasitas
Passenger Elevators
: HYUNDAI
Lebar pintu (opening width): $1000 \mathrm{~mm}$
Dimensi ruang luncur

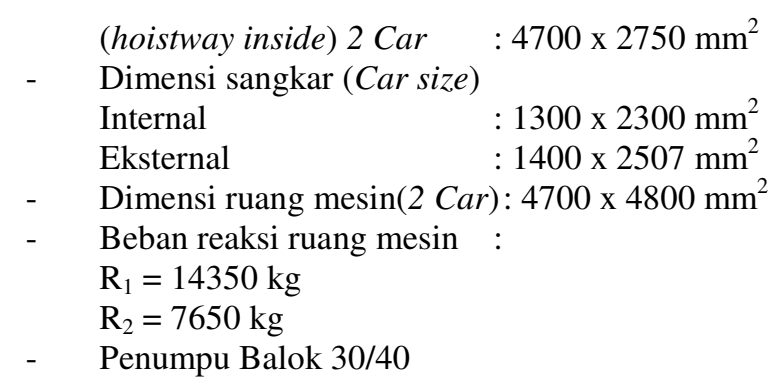

4. Perencanaan Tangga

- Tinggi antar lantai

- Panjang bordes

- Panjang tangga

- Lebar tangga

- Lebar injakan (i)

- Lebar pegangan tangga

$=300 \mathrm{~cm}$

$=300 \mathrm{~cm}$

$=210 \mathrm{~cm}$

$=120 \mathrm{~cm}$

$=30 \mathrm{~cm}$

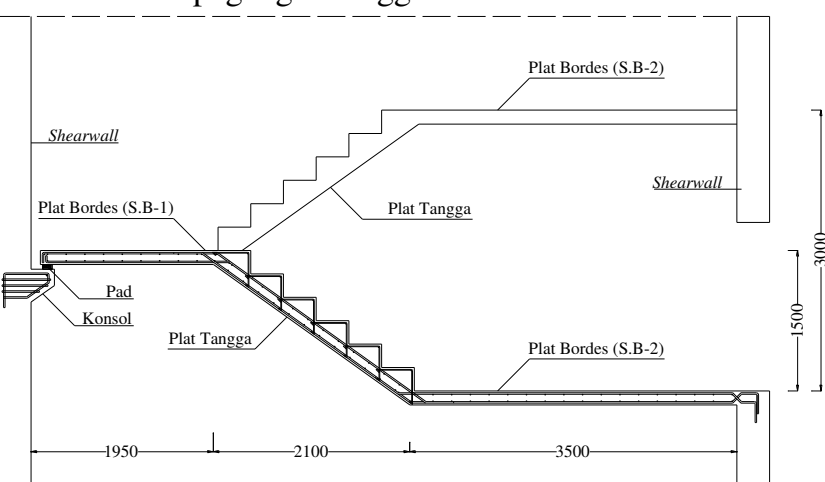

Gambar 2. Potongan Tangga

\section{B. Analisis Struktur}

Pemodelan adalah tahap awal dari perencanaan untuk mendapatkan gaya dalam elemen struktur yang digunakan untuk mendesain kebutuhan tulangan dan penampang elemen struktur yang ditinjau. Untuk memodelkan bangunan digunakan program bantu analisis struktur (SAP). Setelah dimodelkan, pemodelkan dibebani sesuai dengan perencanaan. Kemudian dilakukan analisis struktur sebagai kontrol sesuai dengan yang tercantum pada SNI [4]. Untuk pemodelan bangunan pada Tugas Akhir ini dapat dilihat pada gambar 3 .

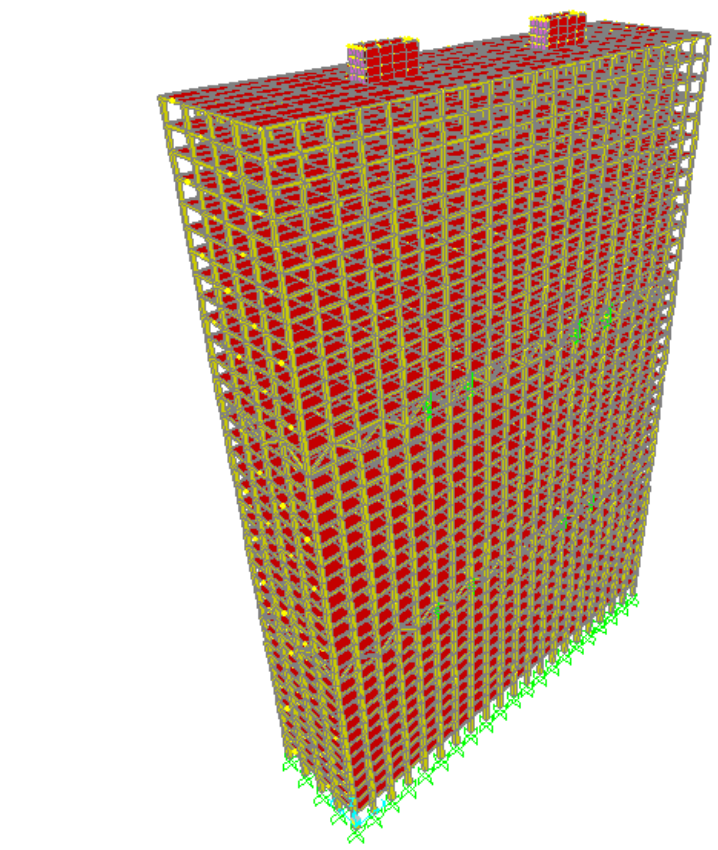

Gambar 3. Pemodelan desain modifikasi struktur.

\section{Pembebanan}

Rincian pembebanan untuk beban mati adalah sebagai berikut:
a. Pelat atap $\mathrm{q}_{\mathrm{D}}=416 \mathrm{~kg} / \mathrm{m}^{2}$
b. Pelat lantai $\mathrm{q}_{\mathrm{D}}=412 \mathrm{~kg} / \mathrm{m}^{2}$

Rincian pembebanan untuk beban hidup adalah sebagai berikut : 

a. Lantai atap $\quad=87,054 \mathrm{~kg} / \mathrm{m}^{2}$
b. Lantai Apartemen $=195,72 \mathrm{~kg} / \mathrm{m}^{2}$

2. Kombinasi Pembebanan

Kombinasi pembebanan yang dipakai pada struktur gedung ini mengacu pada SNI [4].

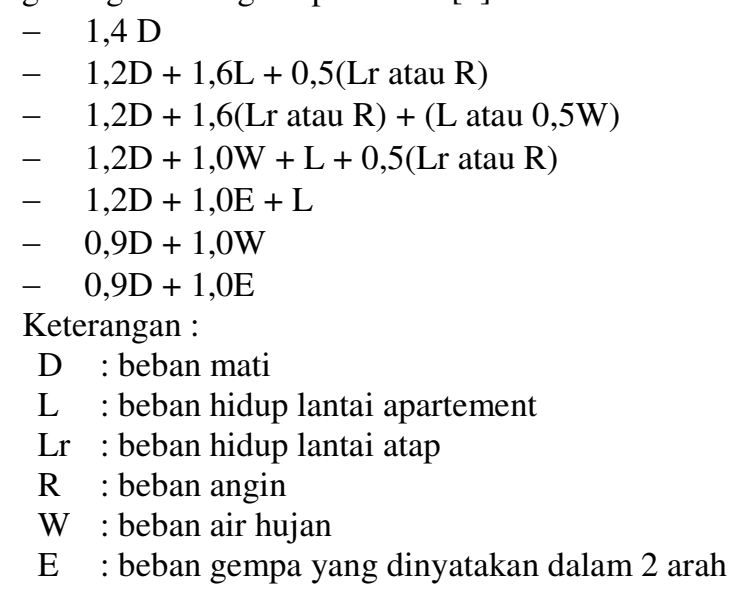

3. Kontrol Desain

a. Berat Sendiri Bangunan

Tujuan menghitung berat sendiri bangunan secara manual adalah untuk dibandingkan dengan berat sendiri output SAP. Hal tersebut untuk memastikan beban yang di-input ke SAP sudah benar. Toleransi selisih antara perhitungan manual dan output tidak boleh lebih dari $10 \%$. Sehingga didapatkan hasil toleransi sebesar $1,91 \%$, maka pemodelan dapat digunakan

b. Kontrol Jumlah Respon Ragam

Sesuai dengan yang tercantum pada SNI [4], dimana respon ragam harus memenuhi minimal $90 \%$ dari massa aktual dalam masing - masing arah.

Dari analisis SAP didapat partisipasi massa pada arah X dan Y sebesar 99,9\% pada moda ke 117. Maka dapat disimpulkan analisis struktur yang sudah dilakukan telah memenuhi syarat yang terdapat pada SNI [4].

c. Kontrol Periode Struktur

Pada tahap perhitungan perioda struktur dan skala gaya gempa digunakan faktor reduksi gempa (R) sebesar 7, dan faktor keutamaan gempa $\left(I_{e}\right)=1$. Penentuan perioda struktur akan berpengaruh pada skala gaya gempa, baik untuk desain maupun untuk kontrol simpangan antar lantai.

Dari hasil analisis SAP periode dan frekuensi struktur didapat $\mathrm{T}=7,25 \mathrm{~s} .<\mathrm{C}_{\mathrm{u}} . \mathrm{T}=1,4.1,75=2,446 \mathrm{~s}$

Maka digunakan nilai $\mathrm{T}$ untuk batas atas yaitu 2,446 $\mathrm{s}$ dimana nilai tersebut digunakan untuk factor pengali pada skala gaya gempa.

d. Kontrol Skala Gaya Gempa

Dari hasil analisis menggunakan program SAP didapatkan nilai gaya geser dasar (base shear) sebagai berikut:

Tabel 1.

$\mathrm{V}_{\text {Dinamik }}$ output SAP

TABLE: Base Reactions

\begin{tabular}{ccccc} 
OutputCase & CaseType & StepType & GlobalFX & GlobalFY \\
\hline Text & Text & Text & Tonf & Tonf \\
EX & LinRespSpec & Max & 1456.53 & 303.893 \\
EY & LinRespSpec & Max & 436.65 & 1013.702 \\
\hline \hline
\end{tabular}

Kontrol :

Untuk gempa arah $\mathrm{X}$ :

Vdinamik $>85 \%$. Vstatik

$1456,53 \mathrm{~T}>85 \% .1943,81 \mathrm{~T}$

$1456,53 \mathrm{~T}>1645,063 \mathrm{~T} \quad($ Not OK...!)

Untuk gempa arah Y :

Vdinamik $>85 \%$. Vstatik

$1013,70 \mathrm{~T}>85 \% .1943,81 \mathrm{~T}$

$1013,70 \mathrm{~T}>1645,063 \mathrm{~T}$ (Not OK...!) maka harus diperbesar dengan faktor skala $0,85 . \frac{C s \cdot W}{V}$.

Untuk arah $\mathrm{X}$ dikali dengan $\mathrm{SF}=1,129$

Untuk arah Y dikali dengan $\mathrm{SF}=1,624$

\section{e. Kontrol Simpangan Bangunan (Drift)}

Pembatasan simpangan antar lantai suatu struktur bertujuan untuk mencegah kerusakan non-struktur dan ketidak nyamanan penghuni.

Berikut disajikan dua grafik yang menunjukan pengaruh jumlah dan letak outrigger terhadap simpangan bangunan.

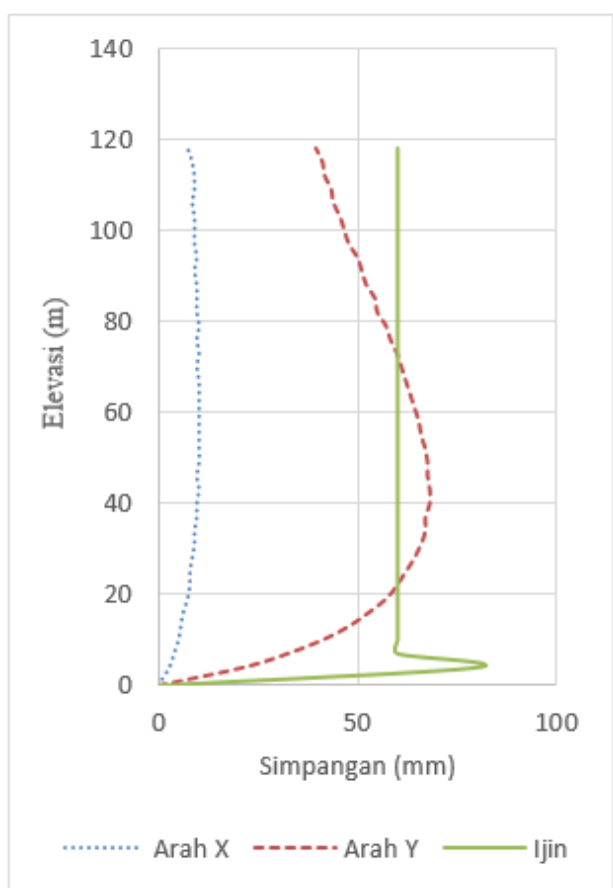

Gambar 4. Simpangan Akibat Gempa Tanpa Outrigger

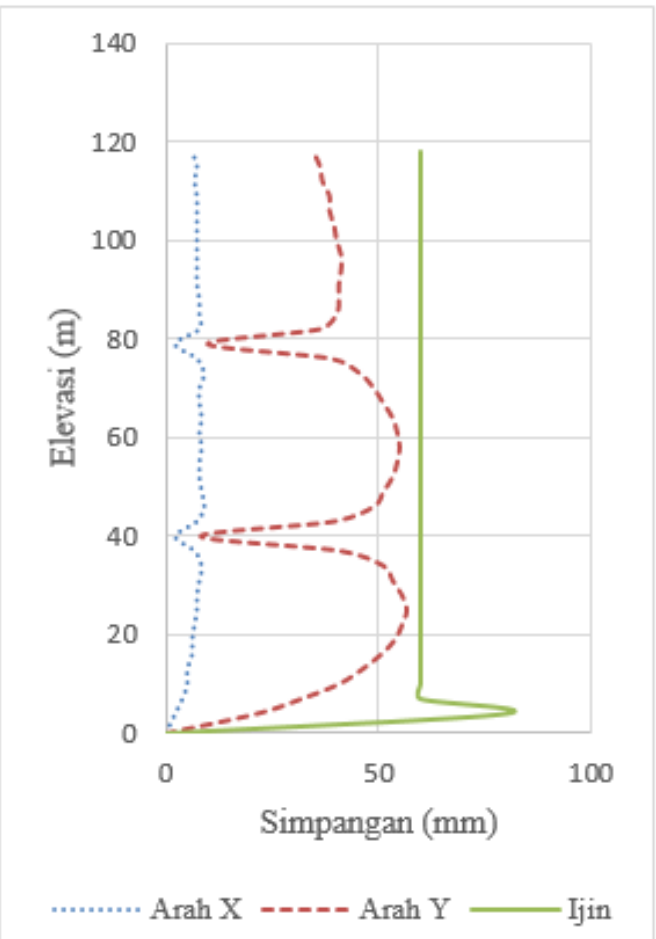

Gambar 5. Simpangan Akibat Gempa dengan 2 Outrigger pada Lt.13 \& 26.

\section{f. Kontrol P-Delta}

Berdasarkan SNI [4], pengaruh P-Delta dapat diabaikan bila koefisien stabilitas $(\theta) \leq 0,1$ dengan persamaan untuk mencari koefisien stabilitas adalah sebagai berikut:

$$
\theta=\frac{P_{x} \cdot \Delta \cdot I_{e}}{V_{x} \cdot h_{s x} \cdot C_{d}}
$$

Berdasarkan rumus diatas didapatkan koefisien stabilitas maksimal untuk arah $\mathrm{X}$ yaitu $0,014<0,1$ dan tabel 6.26 untuk 
arah Y sebesar 0,098 < 0,1 maka pengaruh P-Delta pada kedua arah bangunan dapat diabaikan.

\section{Struktur Primer dan Outrigger}

\section{Balok Induk}

Balok Induk direncanakan sesuai preliminary desain dengan dimensi 30/40, dan mengacu pada SNI [5], dimana didapatkan hasil seperti berikut berikut:

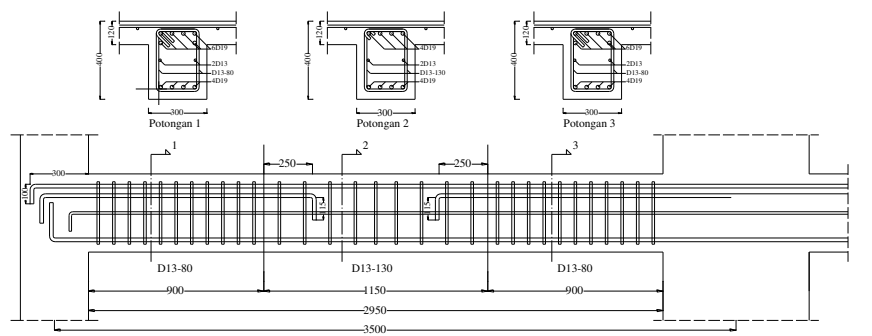

Gambar 6. Sket hasil perhitungan penulangan balok induk tipe B1-5

\section{Kolom}

Kolom didesain sesuai SNI [5], dimana untuk perhitungan kebutuhan penulangan kolom digunakan program bantu SpColumn dan didapat hasil seperti berikut:

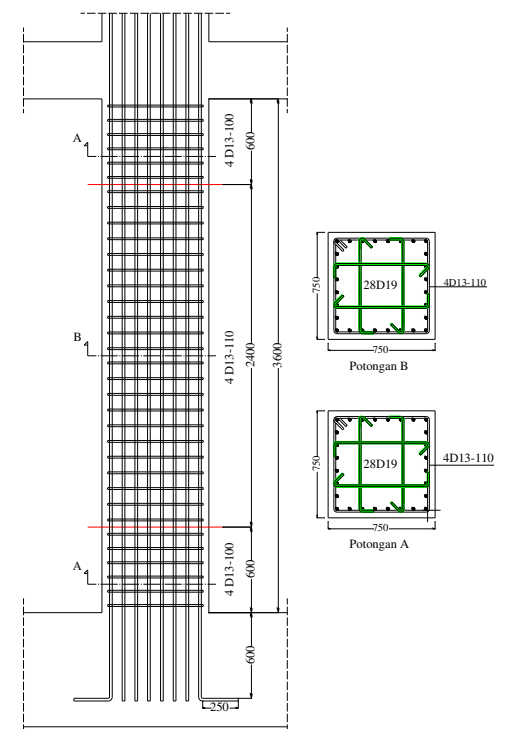

Gambar 7. Sket hasil perhitungan penulangan kolom tipe K1.

\section{Hubungan Balok Kolom}

Desain HBK direncanakan sesuai SNI [5], dimana pasal tersebut berlaku untuk HBK dengan sistem struktur khusus dan diperoleh hasil seperti berikut:

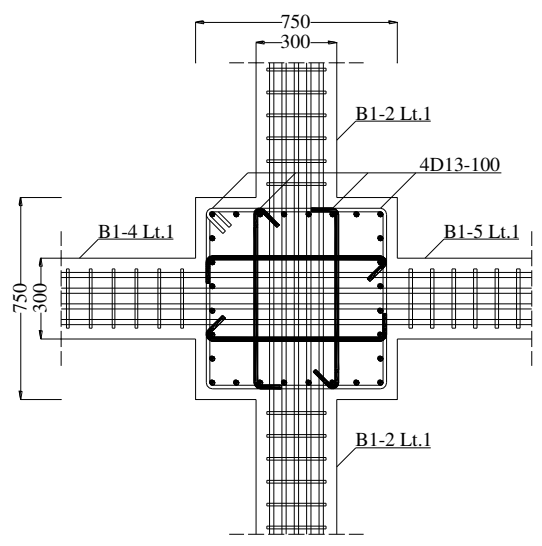

Gambar 8. Sket hasil perhitungan tulangan pada HBK.

\section{Shearwall}

Shearwall berperan sebagai inti dari bangunan (corewall). Dimana pada bangunan ini shearwall direncanakan menggunakan tata cara perencanaan untuk dinding struktur khusus sesuai dengan SNI [5]. Dengan hasil yang dapat dilihat pada gambar berikut:

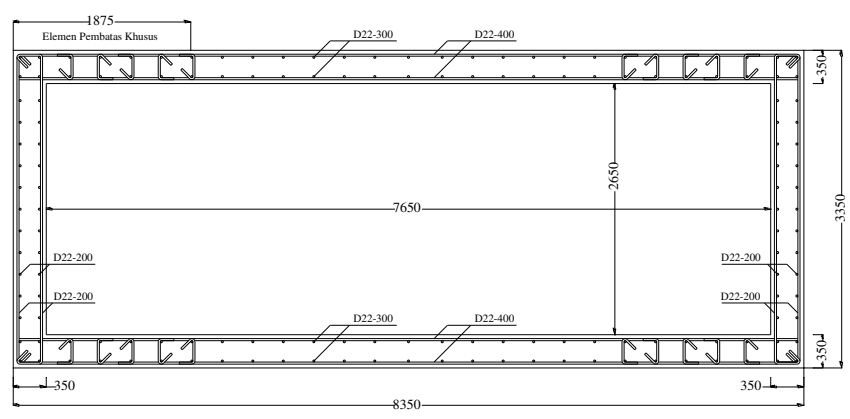

Gambar 9. Sket hasil perhitungan tulangan Shearwall.

\section{Balok Outrigger}

Pada Struktur Apartemen Puncak Dharma Husada Surabaya ini elemen balok outrigger didesain menggunakan balok tinggi sesuai SNI [5], dengan hasil yang didapatkan sesuai gambar berikut:

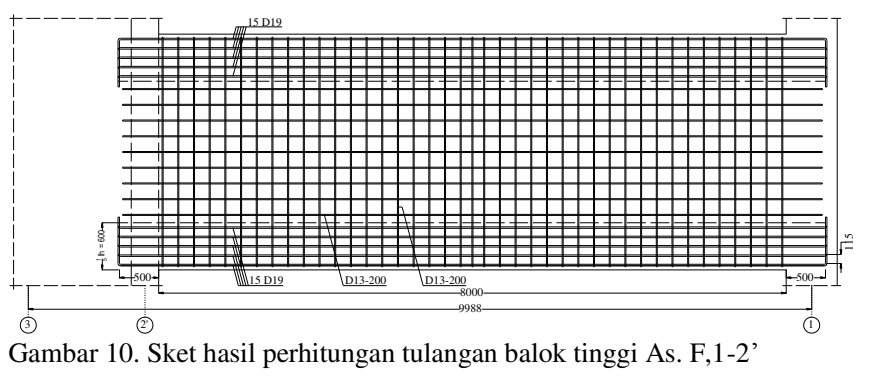

\section{Belt Truss}

Elemen belt tuss didesain menggunakan rangka baja yang mengacu pada SNI [6]. Dimana elemen belt tuss hanya didesain menerima gaya tarik dan tekan saja, untuk sambungan yang digunakan menggunakan sambungan tipe simple connector yang terdiri dari pelat landas dan angkur mutu tinggi yang nilainya didesain sesuai pasal J. berikut merupakan hasil desain belt truss :

- Profil pakai : WF 400 x 400 x 13 x 21

- Pelat landas $\mathrm{t}=50 \mathrm{~mm}$

- Angkur: Tipe $=\mathrm{A} 490$

$$
\begin{array}{ll}
\varnothing & =27 \mathrm{~mm} \\
\mathrm{~F}_{\mathrm{nt}} & =780 \mathrm{MPa} \\
\mathrm{F}_{\mathrm{nv}} & =457 \mathrm{MPa}
\end{array}
$$

- Las : Tipe $=\mathrm{F}_{\mathrm{E} 60 \mathrm{xx}}$

$$
\mathrm{F}_{\mathrm{uw}}=421,8 \mathrm{MPa}
$$

$$
\mathrm{a}=10 \mathrm{~mm}
$$

Gambar hasil perhitungan dapat dilihat seperti berikut:

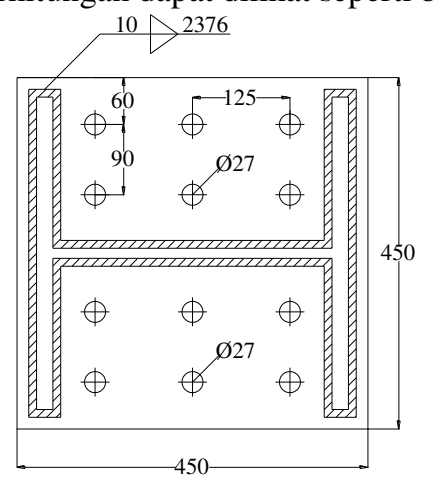

Gambar 11. Sket desain sambungan belt truss.

\section{PENUTUP}

\section{A. Kesimpulan}

Dari perhitungan-perhitungan yang telah dijelaskan pada bab-bab sebelumnya didapatkan kesimpulan sesuai tujuan penulisan tugas akhir ini yaitu penulis dapat merencanakan modifikasi gedung Apartemen Puncak Dharma Husada Surabaya dengan menggunakan kombinasi shear wall dan outrigger system dengan gambar teknis pada lampiran dan hasil analisis sebagai berikut. 
1. Dari hasil analisis beban gempa, struktur gedung termasuk ke dalam kategori desain seismik E dengan demikian dilakukan pendekatan pada konfigurasi sistem ganda yang diterapakan adalah SRPMK dan SDSK, karena untuk sistem outrigger sendiri belum ada syarat yang mengikat untuk desain sistem strukturnya, oleh sebab itu dilakukan pendekatan pada sistem ganda dimana nilai $\mathrm{R}$ yang digunakan adalah 7 untuk factor pengali pembesaran gaya gempanya.

2. Dari program analisis struktur didapatkan kontrol partisipasi massa memenuhi syarat yaitu pada mode 117 sebesar 99,9\%,kontrol waktu getar alami (T) sebesar 2,466 detik ,kontrol nilai akhir respon spektrum V dinamik arah X dan Y sebesar 1645,39 T dan 1645,221 $T$, kontrol pengaruh P-Delta yang menunjukkan hasil bahwa pengaruh P-Delta pada kedua arah struktur dapat diabaikan karena nilai stabilitas maksimal struktur baik arah X maupun arah Y menunjukkan hasil kurang dari 0,1 ,dan yang terakhir memenuhi kontrol drift (simpangan) dengan selisih antara simpangan ijin dan simpangan yang terjadi pada tingkat yang keritis mencapai $3,35 \mathrm{~mm}$ dimana hasil tersebut merupakan nilai yang terbesar diantara beberapa model yang sudah dilakukan.

\section{B. Saran}

Berdasarkan hasil perencanaan yang telah dilakukan, maka disarankan:
1. Untuk menghasilkan dimensi struktur primer yang efisien dan memenuhi syarat-syarat yang ditentukan, maka perlu dilakukan analisis secara bertahap dengan menggunakan dimensi minimum yang ditentukan sampai memperoleh dimensi yang tepat. Dalam hal ini perlu dikontrol diantaranya kontrol partisipasi massa, pengaruh P-Delta, kontrol $\mathrm{Vd} \geq 0,85$ Vs.m, dan kontrol drift bangunan.

2. Untuk disain balok outrigger sendiri perlu dilakukan peninjaun terhadap jumlah dan estimasi letaknya karena jumlah dan penempatan outrigger sangat berpengaruh terhadap penambahan kekakuan pada bangunan yang berdampak pada simpangan yang terjadi. Maka dari itu kebutuhan dan letak dari outrigger pada tiap bangunan berbeda-beda.

\section{DAFTAR PUSTAKA}

$[1]$

Y. Syahriar and M. M. Faishal, "Analisis Perbandingan Efektifitas Struktur Gedung dengan Menggunakan Shearwall dan kombinasi antara Shearwall-Outrigger," J. Tek. POMITS, vol. 1, no. 1, pp. 1-6, 2012.

[2] M. R. Jahanshahi, R. Rahgozar, and M. Malekinejad, "A Simple Approach to Static Analysis of Tall Buildings with a Combined Tube-intube and Outrigger-belt Truss System Subjected to Lateral Loading," Int. J. Eng., vol. 25, no. 3, pp. 289-299, 2012.

[3] W. Goman and H. M., "The Evolution of Outrigger System in Tall Building," Int. J. High-Rise Build., vol. 5, no. 1, pp. 21-30, 2016.

[4] Badan Standarisasi Nasional, "SNI 1726:2012 Tata Cara Perencanaan Ketahanan Gempa Untuk Bangunan Gedung," Jakarta, 2012.

[5] Badan Standar Nasional, "Tata cara Perhitungan Struktur Beton Untuk Bangunan Gedung ( SNI 2847:2013 ),” Jakarta, 2013.

[6] Badan Standardisasi Nasional, "SNI 1729-2015: Spesifikasi untuk Bangunan Gedung Baja Struktural,” Jakarta, 2015. 